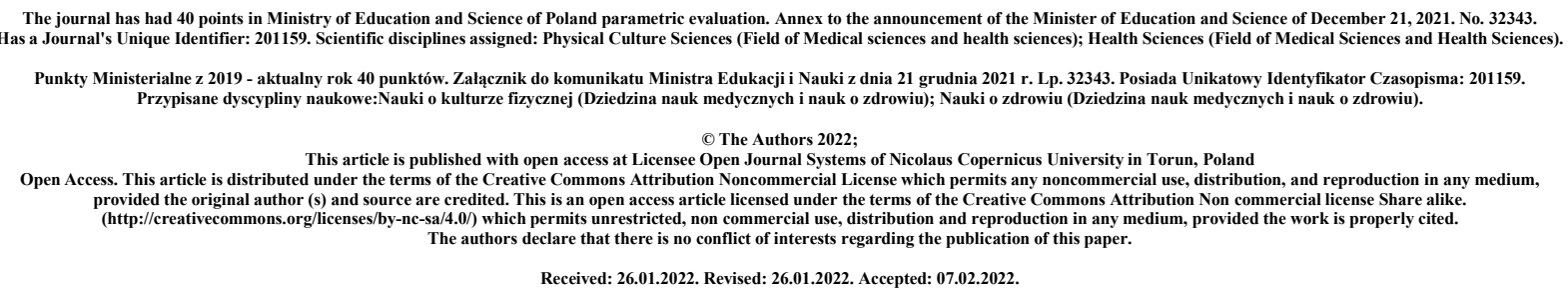

\title{
Excessive body weight as a factor determining the quality of life of young adults
}

\author{
Kamil Grzegorz Redziak
}

ORCID: https://orcid.org/0000-0001-8890-9160

e-mail: kamilredziak@o2.pl

Collegium Medicum, Doctoral School of Jan Kochanowski University in Kielce

Collegium Medicum, The Jan Kochanowski University in Kielce

Aleja IX Wieków Kielc 19A, 25 - 317 Kielce

\section{Summary \\ Introduction}

Obesity has become a global epidemic in the last few decades. Despite the implementation of a number of remedial actions, it has still not been possible to reverse or even stop the trend of its growth. Obesity is a disease that reduces the quality of life. Of particular concern is the fact that it is increasingly found in young people.

\section{Aim of the study}

The aim of the study was to compare the quality of life of young adults in the group of obese people and in the group of people with normal body weight.

\section{Material and methods}

The study was conducted among 105 secondary school students from rural areas. The method of diagnostic survey was used with the use of a proprietary questionnaire containing questions about socio-demographic data and a short version of the questionnaire assessing the quality of life - The World Health Organization Quality of Life (WHOQOL).

\section{Results}

More than half of the people $(60 \%)$ in the study group had a body weight within the normal range, overweight was found in $11.43 \%$ of the respondents, obesity in $20 \%$, and underweight in $8.57 \%$ of the respondents. In all areas included in the WHOQoL questionnaire, significant differences were found in the study group between the obese group and the group of people with normal body weight, as well as those with underweight and overweight. 


\section{Conclusions}

Body weight significantly differentiates the quality of life of the examined students. Mean scores in all domains, i.e. physical, psychological, social, and environmental, differed significantly depending on the BMI level.

Key words: quality of life; overweight; obesity; WHOQoL.

\section{Wprowadzenie}

Nadmierna masa ciała jest istotnym wyzwaniem dla zdrowia publicznego [1]. Zjawisko nadwagi i otyłości towarzyszy człowiekowi niemal od początku jego istnienia. Jednakże $\mathrm{w}$ ostatnich dziesięcioleciach przybrało rozmiar globalnej epidemii i stało się jednym z największych problemów zdrowotnych i społecznych wielu państw [2]. Pomimo prowadzonych działań profilaktycznych, w dalszym ciągu nie udało się odwrócić, a nawet zahamować trendu narastania otyłości $[3,4]$. Rozpowszechnienie otyłości w dzisiejszych czasach przybrało wymiar globalnej epidemii, w szczególności w państwach rozwiniętych oraz $\mathrm{w}$ rozwijających się $[5,6]$. Niepokojącym faktem jest to, że liczba dzieci zarówno z nadwagą jak i otyłością ulega ciągłemu wzrostowi. Co roku liczba dzieci z nadwagą zwiększa się o około 400 tysięcy, a z otyłością o około 85 tysięcy [7]. Według danych Światowej Organizacji Zdrowia (WHO) częstość występowania otyłości w latach 1975-2016 na całym świecie wzrosła prawie trzykrotnie. W 2016 r. ponad 1,9 miliarda dorosłych w wieku 18 lat i starszych miało nadwagę. Spośród nich ponad 650 milionów dorosłych było otyłych. W 2016 r. 39\% dorosłych w wieku 18 lat i starszych (39\% mężczyzn i 40\% kobiet) miało nadwagę. Ogółem w 2016 r. około 13\% światowej populacji dorosłych (11\% mężczyzn i 15\% kobiet) było otyłych [8]. Młodzież w Polsce z masą ciała powyżej normy stanowi większy odsetek niż w większości innych państw europejskich. W Polsce problem ten istnieje u 16,4\% osób w wieku 6-19 lat, co więcej częściej występuję u płci męskiej niż u żeńskiej oraz i stale wzrasta w tempie 2-3\% na dziesięć lat [9].

$\mathrm{W}$ ostatnich latach w literaturze przedmiotu coraz więcej uwagi poświęca się jakości życia. Jakość życia jest obiektem zainteresowania wielu dyscyplin naukowych takich jak medycyna i nauki o zdrowiu, psychologia, pedagogika, socjologia oraz ekonomia [10]. W związku z powyższym w literaturze istnieje duża ilość definicji i niejednokrotnie trudno to pojęcie zdefiniować jednoznacznie. W naukach o zdrowiu najczęściej przywołuje się definicję sprecyzowaną przez Quality of Life Group działającą przy Światowej Organizacji Zdrowia (WHOQOL Group). Jakość życia definiowana jest przez tą organizację jako ,indywidualna percepcja własnej pozycji życiowej $z$ uwzględnieniem warunków kulturowych, systemu wartości $w$ powiązaniu z osobistymi celami, oczekiwaniami, normami, problemami. Wplywa na nią $w$ złożony sposób: zdrowie fizyczne, relacje z innymi ludźmi $i$ ważne dla danej osoby cechy środowiska" [11]. Do badania jakości życia w naukach medycznych i naukach o zdrowiu stosowany jest również wskaźnik jakości życia uwarunkowany stanem zdrowiem (ang.: Health related quality of life - HRQoL), który definiowany jest jako ,subiektywna ocena pacjenta dotyczaca wpływu choroby i stosowanego leczenia na jego funkcjonowanie $w$ zakresie fizycznym, psychicznym i społecznym" [12].

$\mathrm{Z}$ medycznego punktu widzenia otyłość to wieloczynnikowa choroba metaboliczna, która oddziałuje na dobrostan fizyczny, psychiczny i społeczny oraz warunkuje jakość życia człowieka. We współczesnym społeczeństwie kultywuje się trend szczupłej sylwetki, przez co osoby z nadmierną masa ciała nierzadko spotykają się ze stygmatyzacją i dyskryminacją, zarówno w życiu prywatnym, jak i zawodowym, co z kolei przyczynia się do obniżenia jakości życia [13]. 
Otyłość prowadzi do rozwoju wielu chorób przewlekłych, które w dalszej perspektywie nieuchronnie prowadzą do często występujących i niebezpiecznych dla zdrowia i życia powikłań, które również istotnie mogą obniżać jakość życia jednostki. Wśród najczęstszych chorób, których zwiększone ryzyko wystąpienia związane jest otyłością wymienia się cukrzycę typu 2, choroby układu krążenia jak na przykład choroba niedokrwienna, zwał mięśnia sercowego, miażdżycę, udar mózgu- zarówno krwotoczny, jak i niedokrwienny oraz nadciśnienie tętnicze. Oprócz chorób sercowo- naczyniowych nadmierna masa ciała jest istotnym czynnikiem ryzyka chorób nowotworowych takich jak: rak przełyku, żołądka, jelita grubego czy nerki, a także chorób układu mięśniowo-szkieletowego, jak również nierzadko złego stanu psychicznego [14,15].

\section{Cel pracy}

Celem pracy było porównanie jakości życia młodych dorosłych $\mathrm{w}$ grupie osób z otyłością oraz w grupie osób z masą ciała w zakresie normy.

\section{Material i metodyka}

Badanie zostało przeprowadzone wśród uczniów ze szkół średnich pochodzących z terenów wiejskich. W badaniu wzięło udział 105 uczniów, w tym 68 kobiet i 37 mężczyzn. Badania zostały zrealizowane na przełomie października i listopada 2019 roku. Zastosowano metodę sondażu diagnostycznego z użyciem kwestionariusza ankiety własnej konstrukcji zawierającego pytania o dane socjo-demograficzne oraz skróconej wersji ankiety oceniającej jakość życia - The World Health Organization Quality of Life (WHOQOL)- Bref autorstwa Światowej Organizacji Zdrowia.

Kwestionariusz WHOQOL-BREF to skrócona wersja kwestionariusza WHOQOL-100. Jest to narzędzie zaprojektowane niedawno wykorzystywane do oceny jakości życia. W kwestionariuszu tym analizowana jest sytuacja życiowa człowieka w czasie choroby i w trakcie jej leczenia. Ocena ta uwzględnia cztery dziedziny (domeny) życia :

- dziedzina fizyczna- w której pytania dotyczą m.in. obecności bólu fizycznego, satysfakcji $\mathrm{z}$ pracy i funkcjonowania $\mathrm{w}$ codziennym życiu, zażywania leków oraz jakości snu i wypoczynku,

- dziedzina psychologiczna- dotycząca radości w życiu, poczucia sensu życia, koncentracji uwagi, akceptacji wyglądu fizycznego, zadowolenia z siebie oraz częstości doświadczania negatywnych uczuć takich jak rozpacz, przygnębienie, lęk i depresja,

- dziedzina relacji społecznej: dotycząca zadowolenia z relacjami z innymi ludźmi, życia intymnego i zadowolenia ze wsparcia otrzymywanego od przyjaciół,

- dziedzina środowiskowa: dotycząca poczucia bezpieczeństwa, środków finansowych, realizacji zainteresowań, warunków mieszkaniowych, zadowolenia z ochrony zdrowia i transportu.

Ponadto pierwsze pytanie (WHO1) dotyczy postrzegania ogólnej jakości życia, pytanie drugie (WHO2) dotyczy zadowolenia ze swojego zdrowia [16].

Analiza statystyczna została wykonana na podstawie wyników z przeprowadzonych badań za pomocą programu STATISTICA. Zależności między zmiennymi jakościowymi (lub ilościowymi podzielonymi na klasy) zbadano za pomocą testu chi-kwadrat. Przedstawione wyniki testu zawierają wartości statystyki testowej oraz wartość $\mathrm{p}$. Zasadniczo w testowaniu przyjęto poziom istotności testu $\alpha=0,05$, choć $\mathrm{w}$ niektórych przypadkach hipotezę zerową można było odrzucić na poziomie 0,01 lub 0,001 .

\section{Wyniki}

W przeprowadzonym badaniu uczestniczyło w 105 uczniów. Wśród osób biorących udział w badaniu $65 \%$ stanowiły kobiety w liczbie 68 oraz 35\% mężczyźni, co dało liczbę 37 osób. 
Tabela 1. Płeć badanych osób

\begin{tabular}{|l|c|c|}
\hline \multirow{2}{*}{ Pleć } & \multicolumn{2}{|c|}{ Liczba badanych } \\
\cline { 2 - 3 } & $\mathbf{N}$ & $\mathbf{\%}$ \\
\hline Kobieta & 68 & 65 \\
\hline Mężczyzna & 37 & 35 \\
\hline Razem & $\mathbf{1 0 5}$ & $\mathbf{1 0 0}$ \\
\hline
\end{tabular}

Badane osoby były w przedziale wiekowym 1820 lat. Najliczniejszą grupę stanowiły kobiety w wieku 18 lat - $31(29,52 \%)$, nieco mniej liczną grupę stanowiły kobiety w wieku 20 lat 24 $(22,86 \%)$, a najmniej liczną grupą były kobiety w wieku 19 lat 12 (12,38\%). Natomiast w przypadku mężczyzn, najliczniejsza grupę stanowili mężczyźni w wieku 18 lat 16 $(15,24 \%)$, nieco mniej liczną mężczyźni w wieku 19 lat- 12 (11,43\%), a najmniej osób było w wieku 20 lat- 9 (8,57). Ponadto najwięcej badanych było w wieku 18 lat- 47 osób, co stanowiło 44,76\%, następnie w wieku 20 lat- 33 osoby (31,43\%), a najmniej w wieku 19 lat25 osób $(23,81 \%)$.

Tabela 2. Wiek badanych

\begin{tabular}{|l|c|c|c|c|c|c|}
\hline \multirow{3}{*}{ Wiek } & \multicolumn{6}{|c|}{ Liczba badanych } \\
\cline { 2 - 7 } & \multicolumn{2}{|c|}{ Kobiety } & \multicolumn{2}{c|}{ Mężczyźni } & \multicolumn{2}{c|}{ Razem } \\
\cline { 2 - 7 } & $\mathbf{n}$ & $\mathbf{\%}$ & $\mathbf{n}$ & $\mathbf{\%}$ & $\mathbf{n}$ & $\mathbf{\%}$ \\
\hline 18 & 31 & 29,52 & 16 & 15,24 & 47 & 25,76 \\
\hline 19 & 13 & 12,38 & 12 & 11,43 & 33 & 31,43 \\
\hline 20 & 24 & 22,86 & 9 & 8,57 & $\mathbf{1 0 5}$ & $\mathbf{1 0 0}$ \\
\hline Razem & $\mathbf{6 8}$ & $\mathbf{6 4 , 7 6}$ & $\mathbf{3 7}$ & $\mathbf{3 5 , 2 4}$ & & \\
\hline
\end{tabular}

Badane osoby są uczniami liceum i technikum. Do liceum uczęszcza 56 osób, co stanowi 53,33\% ogółu, natomiast do technikum 49 osób, co stanowi 46,67\%. Więcej kobiet uczęszcza do liceum niż do technikum 41 osób $(39,05 \%)$ do liceum i 27 osób $(25,71 \%)$ do technikum. Wśród mężczyzn w liceum uczy się 15 badanych (14,29\%), a w technikum 22 badanych $(20,95 \%)$.

Tabela 3. Typy szkoły, do których uczęszczają badane osoby

\begin{tabular}{|l|c|c|c|c|c|c|}
\hline \multirow{2}{*}{ Typ szkoly } & \multicolumn{7}{|c|}{ Liczba badanych } & \multicolumn{2}{c|}{ Razem } \\
\cline { 2 - 7 } & \multicolumn{2}{|c|}{ Kobiety } & \multicolumn{2}{c|}{ Mężczyźni } & n & \% \\
\cline { 2 - 7 } & $\mathbf{n}$ & $\mathbf{0}$ & 15 & 14,29 & 56 & 53,33 \\
\hline Liceum & 41 & 39,05 & 22 & 20,95 & 49 & 46,67 \\
\hline Technikum & 27 & 25,71 & $\mathbf{3 7}$ & $\mathbf{3 5 , 2 4}$ & $\mathbf{1 0 5}$ & $\mathbf{1 0 0}$ \\
\hline Razem & $\mathbf{6 8}$ & $\mathbf{6 4 , 7 6}$ & &
\end{tabular}

Średnia masa ciała kobiet wynosiła $63,87 \mathrm{~kg}$, a wysokość ciała 1,67m. Zakres wartości BMI kobiet wynosił od $16,53 \mathrm{~kg} / \mathrm{m}^{2}$ do $34,82 \mathrm{~kg} / \mathrm{m}^{2}$, ze średnią $22,72 \mathrm{~kg} / \mathrm{m}^{2}$.

Tabela 4. Charakterystyki liczbowe dla wysokości i masy ciała badanych kobiet

\begin{tabular}{|l|c|c|c|c|}
\hline \multirow{2}{*}{ Zmienna } & \multicolumn{4}{|c|}{$\begin{array}{c}\text { Badane kobiety } \\
\text { N=68 }\end{array}$} \\
\cline { 2 - 5 } & Średnia & Minimum & Maksimum & $\begin{array}{c}\text { Odchylenie } \\
\text { standardowe }\end{array}$ \\
\hline Masa ciała [kg] & 63,87 & 44 & 103 & 13,15 \\
\hline Wysokość ciała [m] & 1,67 & 1,57 & 1,88 & 0,06 \\
\hline BMI & 22,72 & 16,53 & 34,82 & 4,21 \\
\hline
\end{tabular}

Średnia masa ciała mężczyzn wynosiła $82,49 \mathrm{~kg}$, a wysokość ciała 1,78 m. Zakres wartości BMI kobiet wynosił od $17,34 \mathrm{~kg} / \mathrm{m}^{2}$ do $37,03 \mathrm{~kg} / \mathrm{m}^{2}$, ze średnią $25,98 \mathrm{~kg} / \mathrm{m}^{2}$.

Tabela 5. Charakterystyki liczbowe dla wysokości i masy ciała badanych mężczyzn

\begin{tabular}{|c|c|}
\hline & Badani mężczyźni \\
$\mathbf{N}=\mathbf{3 7}$
\end{tabular}




\begin{tabular}{|l|c|c|c|c|}
\hline \multicolumn{1}{|c|}{ Zmienna } & Średnia & Minimum & Maksimum & $\begin{array}{c}\text { Odchylenie } \\
\text { standardowe }\end{array}$ \\
\hline Masa ciała $[\mathrm{kg}]$ & 82,49 & 58 & 120 & 17,52 \\
\hline Wysokość ciała [m] & 1,78 & 1,61 & 1,93 & 0,06 \\
\hline BMI & 25,98 & 17,34 & 37,03 & 5,31 \\
\hline
\end{tabular}

Spośród kobiet, które wzięły udział w badaniu BMI w zakresie normy $(18,5-24,99)$ miało 48 kobiet $(45,71 \%)$, natomiast nadwaga występowała u 6 kobiet $(5,71 \%)$, a otyłość u 8 kobiet $(7,62 \%)$. Z kolei niedowaga wystąpiła u 6 kobiet (5,71\%). Spośród mężczyzn masę ciała w zakresie normy odnotowano u 15 mężczyzn (14,29\%), a nadwagę u 6 mężczyzn $(5,71 \%)$, a otyłość u 13 osób (12,38\%). Niedowaga wystąpiła jedynie u 3 mężczyzn, co stanowiło $2,86 \%$. Ponad połowa osób $(60 \%) \mathrm{w}$ badanej grupie ma masę ciała w zakresie normy, nadwaga wystąpiła u 11,43\% badanych, otyłość u 20\%, a niedowaga u 8,57\% respondowanych.

Tabela 6. Wartość BMI osób w badanej grupie

\begin{tabular}{|c|c|c|c|c|c|c|}
\hline \multirow{3}{*}{$\begin{array}{c}\text { Wartość } \\
\text { BMI }\end{array}$} & \multicolumn{6}{|c|}{ Liczba badanych } \\
\hline & \multicolumn{2}{|c|}{ Kobiety } & \multicolumn{2}{|c|}{ Mężczyźni } & \multicolumn{2}{|c|}{ Razem } \\
\hline & $\mathbf{n}$ & $\%$ & $\mathbf{n}$ & $\%$ & $\mathbf{n}$ & $\%$ \\
\hline Niedowaga & 6 & 5,71 & 3 & 2,86 & 9 & 8,57 \\
\hline Norma & 48 & 45,71 & 15 & 14,29 & 63 & 60 \\
\hline Nadwaga & 6 & 5,71 & 6 & 5,71 & 12 & 11,43 \\
\hline Otyłość & 8 & 7,62 & 13 & 12,38 & 21 & 20 \\
\hline Razem & 68 & 64,76 & 37 & 35,24 & 105 & 100 \\
\hline
\end{tabular}

Tabela 7. Uzyskane w teście WHOQOL-BREF wyniki w poszczególnych domenach w całej badanej populacji.

\begin{tabular}{|l|c|c|c|c|}
\hline \multirow{2}{*}{\multicolumn{1}{|c|}{ Zmienna }} & \multicolumn{4}{c|}{ Statystyki opisowe } \\
\cline { 2 - 5 } & Średnia & Minimum & Maksimum & Odchylenie standardowe \\
\hline Jakość życia & 3,73 & 1 & 5 & 0,91 \\
\hline Zadowolenie ze zdrowia & 3,33 & 1 & 5 & 1,06 \\
\hline Dziedzina fizyczna, DOM1 & 6,70 & 4 & 10 & 1,25 \\
\hline Dziedzina psychologiczna, DOM2 & 8,72 & 5 & 11 & 1,75 \\
\hline Relacja społeczne, DOM3 & 17,35 & 5 & 20 & 4,20 \\
\hline Środowisko, DOM4 & 6,93 & 4 & 10 & 1,58 \\
\hline
\end{tabular}

Tabela 8. Zależność między jakością życia, a BMI.

\begin{tabular}{|c|c|c|c|c|c|c|c|c|c|c|}
\hline \multirow{3}{*}{$\begin{array}{l}\text { BMI kategorie } \\
\text { Jakość } \\
\text { życia }\end{array}$} & \multicolumn{10}{|c|}{ Liczba badanych } \\
\hline & \multicolumn{2}{|c|}{ Niedowaga } & \multicolumn{2}{|c|}{ Norma } & \multicolumn{2}{|c|}{ Nadwaga } & \multicolumn{2}{|c|}{ Otylość } & \multicolumn{2}{|c|}{ Razem } \\
\hline & $\mathbf{N}$ & $\%$ & n & $\%$ & n & $\%$ & n & $\%$ & $\mathbf{N}$ & $\%$ \\
\hline Bardzo zła & 0 & 0,00 & 0 & 0,00 & 0 & 0,00 & 1 & 0,95 & 1 & 0,95 \\
\hline Zła & 1 & 0,95 & 3 & 2,86 & 0 & 0,00 & 5 & 4,76 & 9 & 8,57 \\
\hline $\begin{array}{l}\text { Ani dobra ani } \\
\text { zła }\end{array}$ & 0 & 0,00 & 18 & 17,14 & 4 & 3,81 & 6 & 5,71 & 28 & 26,67 \\
\hline Dobra & 8 & 7,62 & 29 & 27,62 & 5 & 4,76 & 4 & 3,81 & 46 & 43,81 \\
\hline
\end{tabular}




\begin{tabular}{|l|c|c|c|c|c|c|c|c|c|c|}
\hline Bardzo dobra & 0 & 0,00 & 13 & 12,38 & 3 & 2,86 & 5 & 4,76 & 21 & 20,00 \\
\hline Razem & $\mathbf{9}$ & $\mathbf{8 , 5 7}$ & $\mathbf{6 3}$ & $\mathbf{6 0 , 0 0}$ & $\mathbf{1 2}$ & $\mathbf{1 1 , 4 3}$ & $\mathbf{2 1}$ & $\mathbf{2 0 , 0 0}$ & $\mathbf{1 0 5}$ & $\mathbf{1 0 0}$ \\
\hline
\end{tabular}

Zbadano zależność między jakością życia, a BMI. Wartości testu chi-kwadrat wynoszą: $\chi^{2}=23,88 ; p=0,02$, co oznacza, że istnieje zależność między poziomem jakości życia, a poziomami BMI

Tabela 9. Zależność między zadowoleniem ze zdrowia, a BMI

\begin{tabular}{|l|c|c|c|c|c|c|c|c|c|c|}
\hline \multirow{2}{*}{$\begin{array}{l}\text { Zadowolenie } \\
\text { ze zdrowia }\end{array}$} & \multicolumn{9}{|c|}{ Liczba badanych } \\
\cline { 2 - 13 } & \multicolumn{2}{|c|}{ Niedowaga } & \multicolumn{2}{|c|}{ Norma } & \multicolumn{2}{c|}{ Nadwaga } & \multicolumn{2}{|c|}{ Otylość } & \multicolumn{2}{c|}{ Razem } \\
\cline { 2 - 13 } & $\mathbf{n}$ & $\mathbf{9}$ & $\mathbf{n}$ & $\mathbf{\%}$ & $\mathbf{n}$ & $\mathbf{\%}$ & $\mathbf{n}$ & $\mathbf{\%}$ & $\mathbf{N}$ & $\mathbf{\%}$ \\
\hline $\begin{array}{l}\text { Bardzo } \\
\text { niezadowolony }\end{array}$ & 0 & 0,00 & 2 & 1,90 & 1 & 0,95 & 5 & 4,76 & 8 & 7,62 \\
\hline Niezadowolony & 0 & 0,00 & 7 & 6,67 & 1 & 0,95 & 5 & 4,76 & 13 & 12,38 \\
\hline $\begin{array}{l}\text { Ani zadowolony } \\
\text { ani niezadowolony }\end{array}$ & 3 & 2,86 & 19 & 18,10 & 3 & 2,86 & 5 & 4,76 & 30 & 28,57 \\
\hline Zadowolony & 5 & 4,76 & 27 & 25,71 & 6 & 5,71 & 6 & 5,71 & 44 & 41,90 \\
\hline $\begin{array}{l}\text { Bardzo } \\
\text { zadowolony }\end{array}$ & 1 & 0,95 & 8 & 7,62 & 1 & 0,95 & 0 & 0,00 & 10 & 9,52 \\
\hline Razem & $\mathbf{9}$ & $\mathbf{8 , 5 7}$ & $\mathbf{6 3}$ & $\mathbf{6 0 , 0 0}$ & $\mathbf{1 2}$ & $\mathbf{1 1 , 4 3}$ & $\mathbf{2 1}$ & $\mathbf{2 0 , 0 0}$ & $\mathbf{1 0 5}$ & $\mathbf{1 0 0}$ \\
\hline
\end{tabular}

Zbadano zależność między zadowoleniem ze swojego zdrowia, a BMI. Wartości testu chikwadrat wynoszą: $\chi^{2}=17,67 ; p=0,12$, co oznacza, że zadowolenie ze zdrowia nie zależy od wartości BMI.

Tabela 10. Zależność między wynikiem uzyskanym w dziedzinie fizycznej, a BMI

\begin{tabular}{|l|c|c|c|c|c|c|c|c|c|c|}
\hline \multirow{2}{*}{$\begin{array}{l}\text { Uzyskany } \\
\text { wynik }\end{array}$} & \multicolumn{9}{|c|}{ Liczba badanych } \\
\cline { 2 - 13 } & Niedowaga & \multicolumn{2}{c|}{ Norma } & \multicolumn{2}{c|}{ Nadwaga } & \multicolumn{2}{|c|}{ Otylość } & \multicolumn{2}{c|}{ Razem } \\
\cline { 2 - 12 } & $\mathbf{n}$ & $\mathbf{\%}$ & $\mathbf{n}$ & $\mathbf{\%}$ & $\mathbf{n}$ & $\mathbf{\%}$ & $\mathbf{n}$ & $\mathbf{\%}$ & $\mathbf{N}$ & $\%$ \\
\hline 4 & 0 & 0,00 & 2 & 1,90 & 0 & 0,00 & 2 & 1,90 & 4 & 3,81 \\
\hline 5 & 1 & 0,95 & 6 & 5,71 & 0 & 0,00 & 6 & 5,71 & 13 & 12,38 \\
\hline 6 & 1 & 0,95 & 12 & 11,43 & 6 & 5,71 & 7 & 6,67 & 26 & 24,76 \\
\hline 7 & 6 & 5,71 & 27 & 25,71 & 3 & 2,86 & 4 & 3,81 & 40 & 38,10 \\
\hline 8 & 0 & 0,00 & 9 & 8,57 & 2 & 1,90 & 1 & 0,95 & 12 & 11,43 \\
\hline 9 & 1 & 0,95 & 7 & 6,67 & 1 & 0,95 & 0 & 0,00 & 9 & 8,57 \\
\hline 10 & 0 & 0,00 & 0 & 0,00 & 0 & 0,00 & 1 & 0,95 & 1 & 0,95 \\
\hline Razem & $\mathbf{9}$ & $\mathbf{8 , 5 7}$ & $\mathbf{6 3}$ & $\mathbf{6 0 , 0 0}$ & $\mathbf{1 2}$ & $\mathbf{1 1 , 4 3}$ & $\mathbf{2 1}$ & $\mathbf{2 0 , 0 0}$ & $\mathbf{1 0 5}$ & $\mathbf{1 0 0}$ \\
\hline
\end{tabular}


Zbadano zależność między wynikiem uzyskanym w dziedzinie fizycznej, a BMI. Wartości testu chi-kwadrat wynoszą: $\chi^{2}=28,01 ; p=0,6$, co oznacza, że wynik uzyskany $w$ dziedzinie fizycznej nie zależy od wartości BMI.

Tabela 11. Zależność między wynikiem uzyskanym w dziennie psychologicznej, a BMI.

\begin{tabular}{|c|c|c|c|c|c|c|c|c|c|c|}
\hline \multirow{3}{*}{$\begin{array}{l}\text { Uzyskany } \\
\text { Wynik }\end{array}$} & \multicolumn{10}{|c|}{ Liczba badanych } \\
\hline & \multicolumn{2}{|c|}{ Niedowaga } & \multicolumn{2}{|c|}{ Norma } & \multicolumn{2}{|c|}{ Nadwaga } & \multicolumn{2}{|c|}{ Otylość } & \multicolumn{2}{|c|}{ Razem } \\
\hline & $\mathbf{n}$ & $\%$ & $\mathbf{n}$ & $\%$ & $\mathbf{n}$ & $\%$ & $\mathbf{n}$ & $\%$ & $\mathbf{N}$ & $\%$ \\
\hline 5 & 0 & 0,00 & 3 & 2,86 & 1 & 0,95 & 4 & 3,81 & 8 & 7,62 \\
\hline 6 & 0 & 0,00 & 4 & 3,81 & 0 & 0,00 & 5 & 4,76 & 9 & 8,57 \\
\hline 7 & 2 & 1,90 & 3 & 2,86 & 0 & 0,00 & 1 & 0,95 & 6 & 5,71 \\
\hline 8 & 0 & 0,00 & 6 & 5,71 & 1 & 0,95 & 4 & 3,81 & 11 & 10,48 \\
\hline 9 & 4 & 3,81 & 18 & 17,14 & 5 & 4,76 & 5 & 4,76 & 32 & 30,48 \\
\hline 10 & 3 & 2,86 & 19 & 18,10 & 2 & 1,90 & 1 & 0,95 & 25 & 23,81 \\
\hline 11 & 0 & 0,00 & 10 & 9,52 & 3 & 2,86 & 1 & 0,95 & 14 & 13,33 \\
\hline Razem & 9 & 8,57 & 63 & 60,00 & 12 & 11,43 & 21 & 20,00 & 105 & 100 \\
\hline
\end{tabular}

Zbadano zależność między wynikiem uzyskanym w dziedzinie psychologicznej, a BMI. Stwierdzono, że rozkład odbiega od normalnego, dlatego też zastosowano nieparametryczny test U- Manna Whitney'a . Wartości testu są następujące $Z=3,543197, p=0,000395$, co oznacza, że BMI wpływa na wyniki uzyskany w dziedzinie psychologicznej.

Tabela 12. Zależność między wynikiem uzyskanym w dziennie relacji społecznych, a BMI

\begin{tabular}{|l|c|c|c|c|c|c|c|c|c|c|}
\hline \multirow{2}{*}{\begin{tabular}{l}
\multirow{2}{*}{$\begin{array}{l}\text { uzyskany } \\
\text { wynik }\end{array}$} \\
\cline { 2 - 13 }
\end{tabular}} & \multicolumn{9}{|c|}{ Niedowaga } & \multicolumn{2}{|c|}{ Norma } & \multicolumn{2}{c|}{ Nadwaga } & \multicolumn{2}{c|}{ Otylość } & \multicolumn{2}{c|}{ Razem } \\
\cline { 2 - 12 } & $\mathbf{n}$ & $\%$ & $\mathbf{n}$ & $\%$ & $\mathbf{n}$ & $\%$ & $\mathbf{n}$ & $\%$ & $\mathbf{N}$ & $\%$ \\
\hline 5 & 0 & 0,00 & 2 & 1,90 & 0 & 0,00 & 2 & 1,90 & 4 & 3,81 \\
\hline 7 & 0 & 0,00 & 1 & 0,95 & 0 & 0,00 & 1 & 0,95 & 2 & 1,90 \\
\hline 9 & 0 & 0,00 & 2 & 1,90 & 0 & 0,00 & 0 & 0,00 & 2 & 1,90 \\
\hline 11 & 0 & 0,00 & 1 & 0,95 & 1 & 0,95 & 2 & 1,90 & 4 & 3,81 \\
\hline 12 & 0 & 0,00 & 2 & 1,90 & 0 & 0,00 & 5 & 4,76 & 7 & 6,67 \\
\hline
\end{tabular}




\begin{tabular}{|c|c|c|c|c|c|c|c|c|c|c|}
\hline 15 & 1 & 0,95 & 2 & 1,90 & 1 & 0,95 & 1 & 0,95 & 5 & 4,76 \\
\hline 16 & 1 & 0,95 & 4 & 3,81 & 1 & 0,95 & 2 & 1,90 & 8 & 7,62 \\
\hline 17 & 0 & 0,00 & 5 & 4,76 & 0 & 0,00 & 2 & 1,90 & 7 & 6,67 \\
\hline 20 & 7 & 6,67 & 44 & 41,90 & 9 & 8,57 & 6 & 5,71 & 66 & 62,86 \\
\hline Razem & 9 & 8,57 & 63 & 60,00 & 12 & 11,43 & 21 & 20,00 & 105 & 100 \\
\hline
\end{tabular}

Zbadano zależność między wynikiem uzyskanym w dziedzinie relacji społecznej, a BMI. Wartości testu chi-kwadrat wynoszą: $\chi^{2}=29,37 ; p=0,21$, co oznacza, że wynik uzyskany $\mathrm{w}$ dziedzinie relacji społecznych nie zależy od wartości BMI.

Tabela 13. Zależność między wynikiem uzyskanym w dziennie środowisko, a BMI.

\begin{tabular}{|l|c|c|c|c|c|c|c|c|c|c|}
\hline \multirow{2}{*}{$\begin{array}{l}\text { Uzyskand } \\
\text { wyniki }\end{array}$} & \multicolumn{9}{|c|}{ BMI } \\
\cline { 2 - 12 } & Niedowaga & \multicolumn{2}{|c|}{ Norma } & \multicolumn{2}{c|}{ Nadwaga } & \multicolumn{2}{|c|}{ Otylość } & \multicolumn{2}{c|}{ Razem } \\
\cline { 2 - 12 } & $\mathbf{n}$ & $\mathbf{9}$ & $\mathbf{N}$ & $\mathbf{\%}$ & $\mathbf{n}$ & $\mathbf{\%}$ & $\mathbf{n}$ & $\mathbf{\%}$ & $\mathbf{N}$ & $\%$ \\
\hline 4 & 0 & 0,00 & 2 & 1,90 & 1 & 0,95 & 5 & 4,76 & 8 & 7,62 \\
\hline 5 & 0 & 0,00 & 10 & 9,52 & 2 & 1,90 & 5 & 4,76 & 17 & 16,19 \\
\hline 6 & 1 & 0,95 & 7 & 6,67 & 0 & 0,00 & 4 & 3,81 & 12 & 11,43 \\
\hline 7 & 2 & 1,90 & 17 & 16,19 & 4 & 3,81 & 2 & 1,90 & 25 & 23,81 \\
\hline 8 & 6 & 5,71 & 14 & 13,33 & 2 & 1,90 & 4 & 3,8 & 26 & 24,76 \\
\hline 9 & 0 & 0,00 & 10 & 9,52 & 3 & 2,86 & 1 & 0,95 & 14 & 13,33 \\
\hline 10 & 0 & 0,00 & 3 & 2,86 & 0 & 0,00 & 0 & 0,00 & 3 & 2,86 \\
\hline Razem & $\mathbf{9}$ & $\mathbf{8 , 5 7}$ & $\mathbf{6 3}$ & $\mathbf{6 0 , 0 0}$ & $\mathbf{1 2}$ & $\mathbf{1 1 , 4 3}$ & $\mathbf{2 1}$ & $\mathbf{2 0 , 0 0}$ & $\mathbf{1 0 5}$ & $\mathbf{1 0 0}$ \\
\hline
\end{tabular}

Zbadano zależność między wynikiem uzyskanym w dziedzinie środowiska, a BMI. Wartości testu chi-kwadrat wynoszą: $\chi^{2}=29,77 ; p=0,04$, co oznacza, że wynik uzyskany $w$ dziedzinie środowiska zależy od wartości BMI.

Tabela 14. Statystyki opisowe dla dziedziny fizycznej w zależności od poziomów BMI

\begin{tabular}{|c|c|c|c|c|}
\hline \multirow{4}{*}{$\begin{array}{c}\text { DOM1: dziedzina } \\
\text { fizyczna }\end{array}$} & ANOVA rang Kruskala-Wallisa: $\mathrm{H}(3, \mathrm{~N}=105)=10,17436 \mathrm{p}=0,0171$ \\
\cline { 2 - 5 } & BMI & Siedrednia & Mediana & $\begin{array}{c}\text { Odchylenie } \\
\text { standardowe }\end{array}$ \\
\cline { 2 - 5 } & Norma & 6,89 & 7,00 & 1,05 \\
\cline { 2 - 5 } & Nadwaga & 6,89 & 7,00 & 1,21 \\
\cline { 2 - 5 } & Otyłość & 6,83 & 6,50 & 1,03 \\
\hline
\end{tabular}

Statystyki opisowe dla zmiennej dziedzina fizyczna w zależności od poziomów BMI obrazuje tabela 14. Na podstawie testu Shapiro Wilka stwierdzono, że rozkład odbiega od normalnego (p we wszystkich grupach są mniejsze niż $\alpha=0,05$ ), dlatego też zastosowano nieparametryczny test Kruskala-Wallisa. Wartość p wynosi 0,0171 , co oznacza, że średnie dla dziedziny fizycznej istotnie różnią się od siebie względem BMI. 


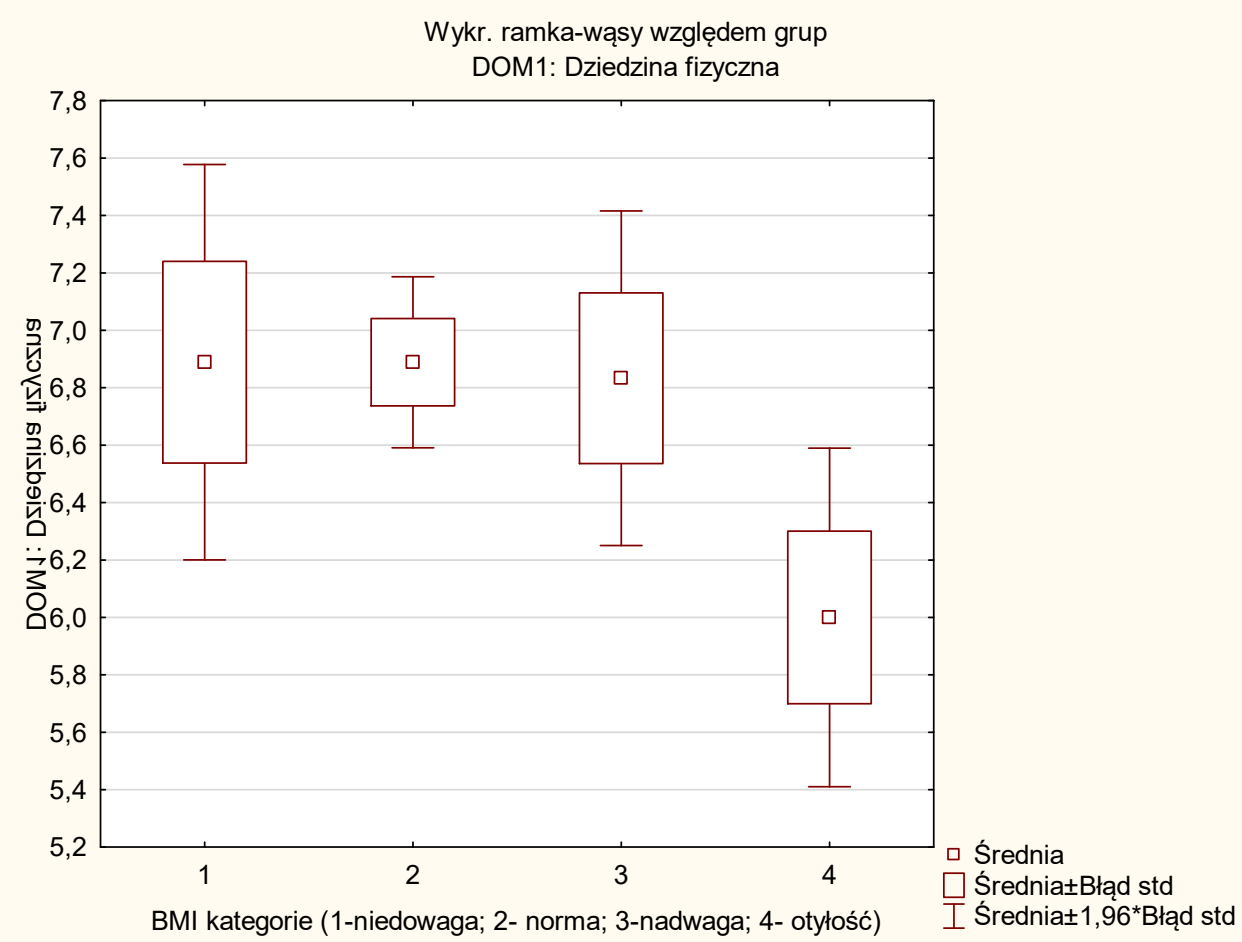

Ryc. 1. Wykres ramka-wąsy.

Z powyższego wykresu wynika, że średnie wyniki w dziedzinie fizycznej istotnie różnią się w zależności od poziomu BMI. Jednakże, po wyłączeniu grupy osób z otyłością, stwierdza się, że wartości w grupie osób z niedowagą, masą ciała w zakresie normy i nadwagą nie różnią się istotnie, co potwierdza powyższy wykres oraz poziom istotności testu chi-kwadrat wynoszący 0,64 .

Tabela 15 Statystyki opisowe dla dziedziny psychologicznej w zależności od poziomów BMI

\begin{tabular}{|c|c|c|c|c|}
\hline \multirow{6}{*}{$\begin{array}{l}\text { DOM2: dziedzina } \\
\text { psychologiczna }\end{array}$} & \multicolumn{4}{|c|}{ ANOVA rang Kruskala-Wallisa : $\mathrm{H}(3, \mathrm{~N}=105)=14,86563 \mathrm{p}=0,0019$} \\
\hline & BMI & Średnia & Mediana & $\begin{array}{c}\text { Odchylenie } \\
\text { standardowe }\end{array}$ \\
\hline & Niedowaga & 8,89 & 9,00 & 1,67 \\
\hline & Norma & 9,04 & 9,00 & 1,61 \\
\hline & Nadwaga & 9,25 & 9,00 & 1,66 \\
\hline & Otyłość & 7,38 & 8,00 & 1,83 \\
\hline
\end{tabular}

Statystyki opisowe dla zmiennej dziedzina psychologiczna w zależności od poziomów BMI obrazuje tabela 15. Na podstawie testu Shapiro-Wilka stwierdzono, że rozkład odbiega od normalnego, dlatego też zastosowano nieparametryczny test Kruskala-Wallisa. Wartość p wynosi 0,0019, co oznacza, że średnie uzyskane w dziedzinie psychologicznej istotnie różnią się od siebie względem. 


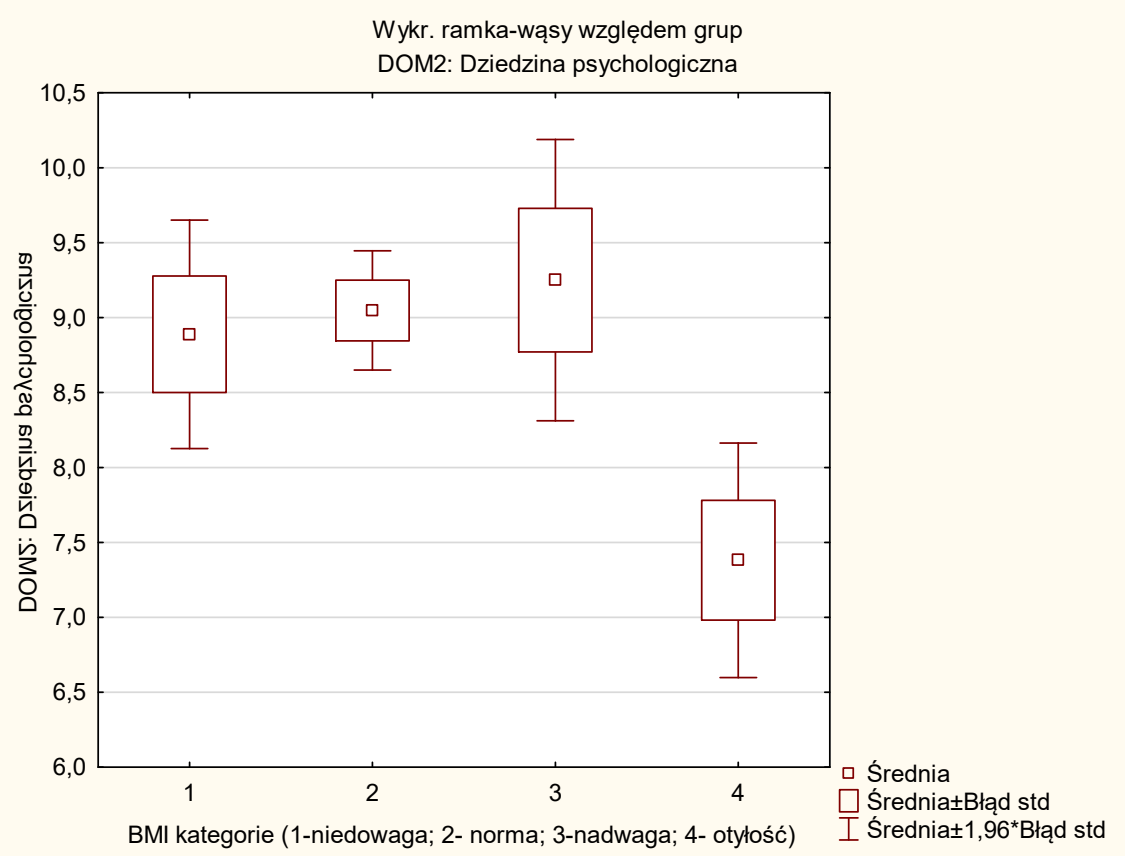

Ryc. 2. Wykres ramka-wąsy.

Z powyższego wykresu wynika, że średnie wyniki w dziedzinie psychologicznej istotnie różnią się w zależności od poziomu BMI. Jednakże, po wyłączeniu grupy osób z otyłością, stwierdza się, że wartości $\mathrm{w}$ grupie osób $\mathrm{z}$ niedowagą, masą ciała $\mathrm{w}$ zakresie normy i nadwagą nie różnią się istotnie, co potwierdza powyższy wykres oraz poziom istotności testu chi-kwadrat wynoszący 0,76 .

Tabela 16 Statystyki opisowe dla relacji społecznych w zależności od poziomów BMI

\begin{tabular}{|c|c|c|c|c|}
\hline \multirow{4}{*}{$\begin{array}{c}\text { DOM3: relacje } \\
\text { społeczne }\end{array}$} & ANOVA rang Kruskala-Wallisa: $\mathrm{H}(3, \mathrm{~N}=105)=15,08366 \mathrm{p}=0,0017$ \\
\cline { 2 - 5 } & BMI & Średnia & Mediana & $\begin{array}{c}\text { Odchylenie } \\
\text { standardowe }\end{array}$ \\
\cline { 2 - 5 } & Norma & 19,00 & 20 & 2,00 \\
\cline { 2 - 5 } & Nadwaga & 17,92 & 20,00 & 3,93 \\
\cline { 2 - 5 } & Otyłość & 18,50 & 20,00 & 2,94 \\
\hline
\end{tabular}

Statystyki opisowe dla zmiennej relacje społeczne w zależności od poziomów BMI obrazuje tabela 16. Na podstawie testu Shapiro Wilka stwierdzono, zmienna nie posiada rozkładu normalnego (poziom istotności p we wszystkich grupach BMI jest mniejszy od 0,05), dlatego też zastosowano nieparametryczny test Kruskala-Wallisa. Wartość p wynosi 0,0017, co oznacza, że średnie wyniki uzyskane w dziedzinie relacji społecznych istotnie różnią się od siebie względem BMI. 


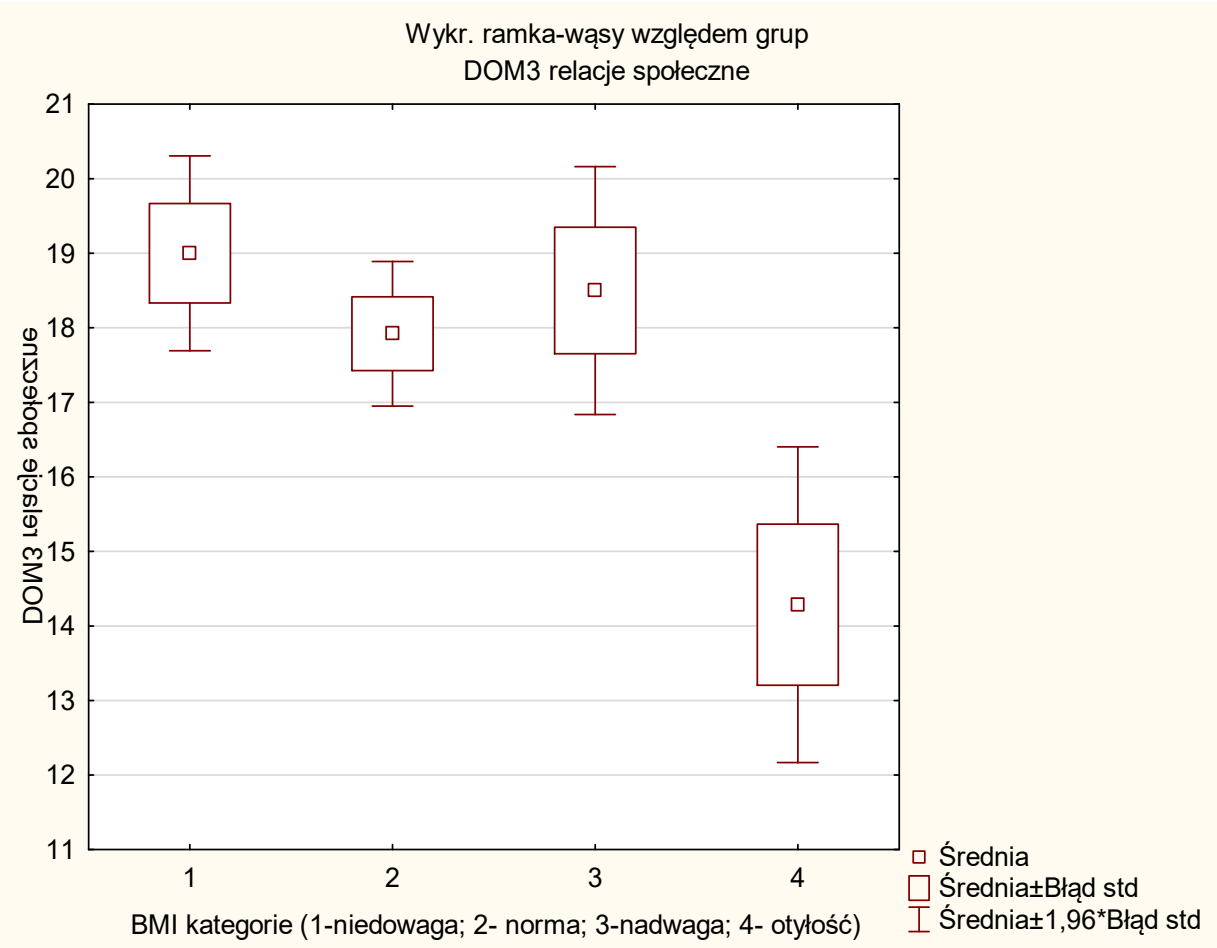

Ryc. 3. Wykres ramka-wąsy.

Z powyższego wykresu wynika, że średnie wyniki w dziedzinie relacji społecznych istotnie różnią się w zależności od poziomu BMI. Jednakże, po wyłączeniu grupy osób z otyłością, stwierdza się, że wartości $\mathrm{w}$ grupie osób $\mathrm{z}$ niedowagą, masą ciała $\mathrm{w}$ zakresie normy i nadwagą nie różnią się istotnie, co potwierdza powyższy wykres oraz poziom istotności testu chi-kwadrat wynoszący 1,00 .

Tabela 17. Statystyki opisowe dla środowisko w zależności od poziomów BMI

\begin{tabular}{|c|c|c|c|c|}
\hline \multirow{4}{*}{ DOM4: środowisko } & \multicolumn{4}{|c|}{ ANOVA rang Kruskala-Wallisa: $\mathrm{H}(3, \mathrm{~N}=105)=10,34567 \mathrm{p}=0,0158$} \\
\cline { 2 - 5 } & BMI & Mediana & $\begin{array}{c}\text { Odchylenie } \\
\text { standardowe }\end{array}$ \\
\cline { 2 - 5 } & Niedowaga & 7,55 & 8,00 & 0,72 \\
\cline { 2 - 5 } & Norma & 7,16 & 7,00 & 1,53 \\
\cline { 2 - 5 } & Nadwaga & 7,08 & 7,00 & 1,68 \\
\cline { 2 - 5 } & Otyłość & 5,90 & 7,00 & 1,53 \\
\hline
\end{tabular}

Statystyki opisowe dla zmiennej środowisko w zależności od poziomów BMI obrazuje tabela 17. Na podstawie testu Shapiro-Wilka stwierdzono, że rozkład odbiega od normalnego, dlatego też zastosowano nieparametryczny test Kruskala-Wallisa. Wartość p wynosi 0,0158, co oznacza, że średnie wyniki uzyskane w dziedzinie środowiska istotnie różnią się od siebie względem poziomów BMI. 


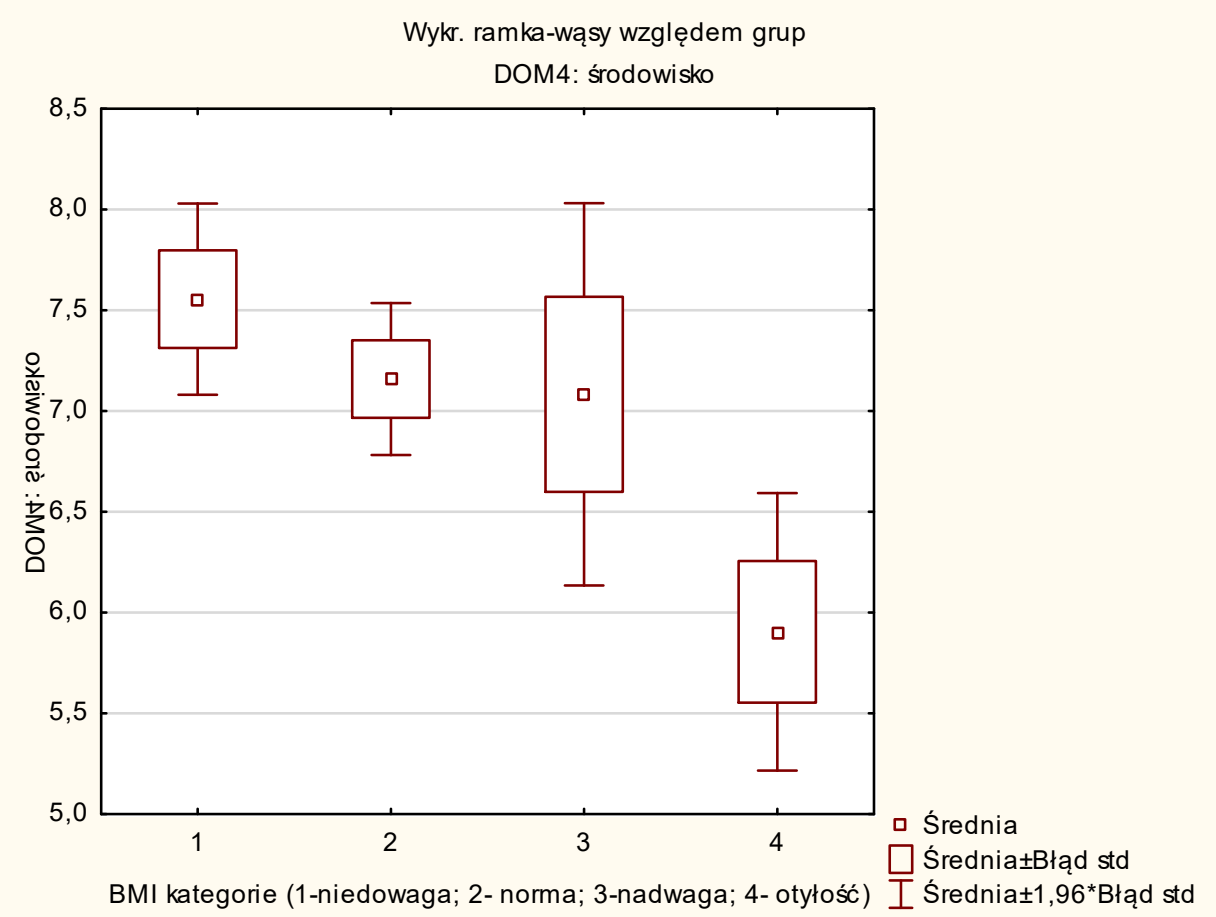

Ryc. 4. Wykres ramka-wąsy.

Z powyższego wykresu wynika, że średnie wyniki w dziedzinie środowiska istotnie różnią się w zależności od poziomu BMI. Jednakże, po wyłączeniu grupy osób z otyłością, stwierdza się, że wartości te $\mathrm{w}$ grupie osób $\mathrm{z}$ niedowagą, masą ciała $\mathrm{w}$ zakresie normy i nadwagą nie różnią się istotnie, co potwierdza powyższy wykres oraz poziom istotności testu chi-kwadrat wynoszący 0,39 .

Tabela 18. Analiza korelacji między wynikami uzyskanymi w różnych dziedzinach

\begin{tabular}{|l|c|c|c|c|c|}
\hline \multicolumn{1}{|c|}{ Zmienna } & Średnia & $\begin{array}{c}\text { Odchylenie } \\
\text { standardowe }\end{array}$ & $\begin{array}{c}\text { DOM1: } \\
\text { dziedzina } \\
\text { fizyczna }\end{array}$ & $\begin{array}{c}\text { DOM2: dziedzina } \\
\text { psychologiczna }\end{array}$ & $\begin{array}{c}\text { DOM3: relacje } \\
\text { spoleczne }\end{array}$ \\
\hline $\begin{array}{l}\text { DOM1: dziedzina } \\
\text { fizyczna }\end{array}$ & 6,70 & 1,25 & 1,000000 & & \\
\hline $\begin{array}{l}\text { DOM2: dziedzina } \\
\text { ssychologiczna }\end{array}$ & 8,72 & 1,75 & 0,65 & 1,000000 & 1,000000 \\
\hline $\begin{array}{l}\text { DOM3: relacje } \\
\text { społeczne }\end{array}$ & 17,35 & 4,20 & 0,59 & 0,61 & 0,61 \\
\hline $\begin{array}{l}\text { DOM4: } \\
\text { środowisko }\end{array}$ & 6,93 & 1,58 & 0,66 & 0,77 & \\
\hline
\end{tabular}

Przeprowadzono analizę korelacji między wynikami uzyskanymi z kwestionariusza WHOQOL-Bref. Stwierdzono, że pomiędzy zmiennymi występuje wysoka i bardzo wysoka siła związku. Wysoka siła związku występuje pomiędzy: dziedziną fizyczną i psychologiczną $(\mathrm{r}=0,65)$, dziedziną fizyczną i relacjami społecznymi $(\mathrm{r}=0,59)$, dziedziną fizyczną i środowiskiem $(\mathrm{r}=0,66)$, dziedziną psychologiczną i relacjami społecznymi $(\mathrm{r}=0,61)$ oraz relacjami społecznymi i środowiskiem $(\mathrm{r}=0,61)$. Natomiast bardzo wysoka siła związku występuje pomiędzy dziedziną psychologiczną i środowiskiem $(\mathrm{r}=0,77)$.

\section{Wnioski}

Masa ciała istotnie różnicuje jakość życia badanych uczniów. Średnie wyniki we wszystkich domenach, tj. dziedzinie fizycznej, psychologicznej, relacji społecznych i środowiska różniły się istotnie w zależności od poziomu BMI. Jednakże, po wyłączeniu grupy osób z otyłością, stwierdzano, że wartości te w grupie osób z niedowagą, masą ciała 
W zakresie normy oraz nadwagą nie różnią się istotnie w przypadku każdej z dziedzin. Osoby z otyłością oceniały swoją jakość życia jako zdecydowanie niższa niż pozostali badani.

\section{Piśmiennictwo}

1. Arroyo-Johnson C, Mincey K.D. Obesity epidemiology trends by race/ethnicity, gender, and education: National Health Interview Survey, 1997-2012. Gastroenterol Clin North Am. 2016; 45(4): 571-579.

2. Avgerinos I.K, Spyrou N, Mantzoros S.Ch, Dalamaga M. Obesity and cancer risk: Emerging biological mechanisms and perspectives. Metabolism Clinical and Experimenta. 2019: 192: 121-135.

3. Busutil R, Espallardo O, Torres A, Martinez-Galdeano L, Zozaya N, Hidalgo-Vega A. The impact of obesity on health-related quality of life in Spain. Health and Quality of Life Outcomes (2017) 15:197.

4. Wahi G, de Souza J.R, Hartmann K, Giglia L, Jack M.S, Anand S.S. Effectiveness of programs aimed at obesity prevention among Indigenous children: A systematic review. Preventive Medicine Reports 2021; 22: 101347.

5. Kurdaningsih SV, Sudargo T, Lusmilasari L. Physical activity and sedentary lifestyle towards teenagers' overweight/obesity status. International Journal of Community Medicine and Public Health 2016; 3: 630-635.

6. Rohde K, Keller M, la Cour Poulsen L, Blüher M. Genetics and epigenetics in obesity. Metabolism Clinical and Experimental. 2019; 92: 37-50.

7. Mendyk K, Antos-Latek K, Kowalik M, Pagacz K, Lewicki M, Obel E. Zachowania prozdrowotne w zakresie odżywiania i aktywności fizycznej u dzieci i młodzieży szkolnej w wieku do 18. roku życia. Piel. Zdr. Publ. 2017; 26(1): 13-17.

8. https://www.who.int/news-room/fact-sheets/detail/obesity-and-overweight [2021.04.20]

9. Kolarczyk EB. Zachowania zdrowotne młodzieży gimnazjalnej i ponadgimnazjalnej. Piel. Zdr. Publ. 2015; 5: 305-310.

10. Petelewicz M., Drabowicz T. Jakość życia - globalnie i lokalnie. Pomiar i wizualizacja. Katedra Socjologii Ogólnej Wydział Ekonomiczno-Socjologiczny Uniwersytet Łódzki. Łódź 2016, s. 13-16.

11. Kupkina A.V, Volosovets O.P, Kryvopustov S.P, Prokhorova P.M, Mozyrska O.V. The impact of overweight and obesity on the quality of life in children with bronchial asthma. Wiad Lek. 2020;73(6):1140-1144.

12. Karimi, M. and Brazier, J. Health, Health-Related Quality of Life, and Quality of Life: What is the Difference? Pharmacoeconomics, 2016; 34 (7), 645-649.

13.Zawisza K, Tobiasz-Adamczyk B, Galas A, Jabłońska K, Grodzicki T. Changes in Body Mass Index and Quality of Life-Population-Based Follow-up Study COURAGE and COURAGE-POLFUS, Poland. Applied Research in Quality of Life (2021) 16:501-526.

14. Skrypnik D, Skrypnik K, Bogdański P. Nowoczesna farmakoterapia nadwagi i otyłości W praktyce klinicznej. Forum Zaburzeń Metabolicznych 2018; 9 (2): 72-80.

15. Chooi Y.C, Ding Ch, Magkos F. The epidemiology of obesity. Metabolizm Clinical and Experimental 2019; 92: 6-10.

16. Cieślik B., Podbielska H. Przegląd wybranych kwestionariuszy oceny jakości życia. Acta Bio-Optica et Informatica Medica. Inżynieria biomedyczna 2015; 2: 102-135.

17. Tałtaj A, Wojtyniak J. Jakość życia mężczyzn po przebytej orchidektomii z powodu nowotworu jądra. W: W drodze do brzegu życia. Red. Krajewska-Kułak E, Łukaszczuk R.C, Lewko J, Kułak W. Uniwersytet Medyczny w Białymstoku. Białystok 2020; 238-253.

18. Pietrzykowska E, Wierusz-Wysocka B. Psychologiczne aspekty nadwagi, otyłości i odchudzania się. Pol Merk Lek. 2008;24(143):472. 
19. Gnacińska-Szymańska M, Dardzińska JA, Majkowicz M i wsp. Ocena jakości życia osób z nadmierną masą ciała za pomocą formularza WHOQOL-BREF. Endokrynol. Otył. Zab. Przem. Mat. 2012;8(4):136-42.

20. Forchan M, Reg OT, Gill SV, et al. Obesity, functional mobility and quality of life. Best Pract Res Clin Endocrinol Metab. 2013;27:129-37.

21. Zielińska-Więczkowska H, Budnik M. Analiza jakości życia pacjentów z nadwagą i otyłością w zależności od wskaźnika masy ciała i czynników socjo-demograficznych. Farm Współ 2016; 9: 110-116.

22. Bertrantdt K. Samoocena a jakość życia i występowanie objawów depresyjnych u osób $\mathrm{z}$ nadwagą $\mathrm{i}$ otyłością $\mathrm{w}$ porównaniu $\mathrm{z}$ osobami o prawidłowej masie ciała. Probl Hig Epidemiol 2011; 92(4): 783-787.

23. Duda M. Poczucie jakości życia a zdrowie lubelskich licealistów. Lubelski Rocznik Pedagogiczny 2016; 35 (3): 257-269.

24. Pimenta F, Bertrand E, Mograbi D, Shinohara H, Landeira-fernandez J. The relationship between obesity and quality of life in Brazilian adults. Front. Psychol.2015; 6:966.

25. Meixner L, Cohrdes C, Schienkiewitz A, Mensik G. Health-related quality of life in children and adolescents with overweight and obesity: results from the German KIGGS survey. BMC Public Health 2020; 20:1722.

26. Kleszczewska D, Mazur J, Dzielska A, Michalska A, Gaspar de Matos M, Santos T, et.al. Zdrowie Psychiczne młodzieży. Raport z badań. Instytut Matki i Dziecka. Warszawa 2018, s. 16.

27. Wiśniewska E, Zagroba M, Ostrowska B, Marcysiak M. Jakość życia w zdrowiu i chorobie - charakterystyka pojęcia. W: Jakość życia w naukach medycznych i społecznych. Tom I. Red. Kowalewska B, Jankowiak B, Rolka H, Krajewska-Kułak E. Uniwersytet Medyczny w Białymstoku. Białystok 2017. s. 43-52. 